\title{
A Comparative Investigation of the Corrosion Resistance and HIC Suceptibility of API 5L X65 and API 5L X80 Steels
}

\author{
Janeth Marlene Quispe-Avilés ${ }^{a} \mathbb{0}^{-}$, Duberney Hincapie-Ladino ${ }^{a}$, Neusa Alonso Falleiros ${ }^{a}$, \\ Hercílio Gomes de Melo ${ }^{a}$ ([) \\ ${ }^{a}$ Departamento de Engenharia Metalúrgica e de Materiais, Escola Politécnica, Universidade de São \\ Paulo - USP, Av. Professor Mello Moraes, 2463, CEP 05508-030, São Paulo, SP, Brasil
}

Received: March 13, 2018; Revised: August 29, 2018; Accepted: November 14, 2018

\begin{abstract}
High strength low alloy (HSLA) steels are used for the construction of pipelines for oil and natural gas transportation. For such applications pipelines must exhibit mechanical resistance and resistance to corrosion and hydrogen induced cracking (HIC). API 5L X65 steels are the main materials used for this purpose. However, for economic reasons, the use of steels of superior grades would be of interest. This work presents a comparative study of the corrosion and HIC resistances of an API 5L X65 and an API 5L X80 steel in deaerated solution A of NACE TM0284 standard. Electrochemical impedance spectroscopy (EIS) and potentiodynamic polarization experiments were performed in non-sour and sour $\left(\mathrm{H}_{2} \mathrm{~S}\right.$-saturated) media, and HIC resistance tests were carried out in the sour medium. Scanning electron microscopy (SEM) and optical microscopy (OM) characterizations of polished and corroded samples were also done. Electrochemical tests showed that the API 5L X80 steel is slightly more susceptible to surface corrosion, which can be probably linked to its higher inclusion content and smaller grain sizes, it was also susceptible to HIC. Mn and S-rich inclusions found in the crack path indicate that this microstructural feature may play a key role in crack propagation and HIC susceptibility
\end{abstract}

Keywords: Microalloyed Steels, API $5 \mathrm{~L}$ steels, EIS, Corrosion Resistance, $\mathrm{NH}_{2} \mathrm{~S}$, HIC.

\section{Introduction}

Oil and natural gas are the main sources of energy in the world and the demand and consumption of their derivatives are constantly growing. In this context, there is an increase in the safety requirements for extraction and transportation of these inputs, as failures can result in severe economic losses and environmental damages. ${ }^{1-2}$ For this reason, to build equipment for the oil and gas industry, it is necessary to use materials that respond satisfactorily to the harsh conditions of the petroleum extraction and transportation network. Among the desired properties, we can list: high mechanical resistance to withstand the high operating pressures, fracture toughness, weldability and resistances to corrosion and hydrogen induced damages in acidic environments. ${ }^{3-4}$

$\mathrm{H}_{2} \mathrm{~S}$ and $\mathrm{CO}_{2}$, normally present in oil fields, in the presence of water, create an extremely aggressive environment, generally referred as sour gas. In such environment, high strength steels may become prone to Hydrogen Induced Cracking (HIC). ${ }^{5-6}$ The problem occurs as a consequence of the diffusion of atomic hydrogen within the steel microstructure, which them are entrapped at specific anchoring sites associated with microstructural defects ${ }^{7-9}$, the recombination of these atoms generates $\mathrm{H}_{2}$ gas leading to pressure build up, which, ultimately, can result in failures due to HIC. ${ }^{10}$ Atomic hydrogen results from corrosion, and its diffusion into the material microstructure is favored by the presence of $\mathrm{H}_{2} \mathrm{~S}$ in the electrolyte and also by the existence of sulfide rich inclusions in the material microstructure. ${ }^{11-12} I n$ the presence of such chemicals and microstructural features, the surface recombination of atomic $\mathrm{H}$ into $\mathrm{H}_{2}$ is hampered ${ }^{13-14}$, thus enhancing the diffusion to the metal microstructure and the occurrence of HIC failures.

High-strength low alloy (HSLA) steels are characterized by their superior mechanical properties when compared to other steels with similar compositions, which are achieved by means of controlled addition of microalloying elements and rigorous production procedures. ${ }^{14-16} \mathrm{However}$, to be used in the oil and gas transportation network they must meet the requirements of the API 5L specification regarding equivalent carbon control, shear boundary (MPa), yield strength (MPa). ${ }^{17-18} \mathrm{Currently}$, the API 5L X65 is the highest grade approved for sour gas application. ${ }^{19-20}$ However, there are high expectations of using higher grades API 5L steels, such as $\mathrm{X} 70$ and $\mathrm{X} 80$, which exhibit superior mechanical strength. This would allow the fabrication of pipelines with thinner walls, resulting in relevant savings. ${ }^{21}$ Therefore, in recent years, the interest in studying the resistance to $\mathrm{HIC}$ of API steels of higher grades has increased with the purpose of using them for pipeline application.

Based on the reasons aforementioned, this article presents a comparative study of the corrosion resistance and HIC susceptibility of two API 5L steels: one of the X65 and the other of the X80 grade. 


\section{Materials and Methods}

\subsection{Materials}

API 5L X65 and X80 grades steels provided as tubes by partner companies were used. Their characteristics and chemical compositions are presented, respectively, in Tables 1 and 2 .

\subsection{Microstructural characterization}

For inclusions analyses, samples were cut parallel to the rolling direction, whereas the microstructural analyses were performed from the rolling cross-section according to ASTM E112 (2013) ${ }^{22}$. The samples were embedded in bakelite (AKA Resin Epoxi 8010), sequentially ground (SultradeStruers) with silicon carbide emery paper up to \#1200 grit, and then polished (Sultrade-Struers) with diamond paste up to $1 \mu \mathrm{m}$. Between each ground and polishing step samples were thoroughly washed with distilled and demineralized water, and at the end they were washed with ethanol, dried in a hot air stream and stored in a desiccator.

The characterizations were performed by means of optical microscopy (OM) (Olympus BX60M) and Scanning Electron Microscopy (SEM) (Olympus Philips XL-30) from polished and from polished and Nital $2 \%\left(\mathrm{HNO}_{3} 2 \%+100\right.$ $\mathrm{ml}$ ethanol, $10 \mathrm{~s}$ ) etched samples.

For inclusions classification the ASTM International E45 standard (2013) ${ }^{23}$ was used, whereas grains sizes determination were performed according to the recommendations of ASTM International E112-113 standard (2013) ${ }^{22}$ using the software IMAGEJ as analytical tool.

SEM images were also acquired form corroded samples.

\subsection{Electrochemical tests and corrosion morphology evaluation}

All electrochemical tests were carried out in solution A of NACE TM0284-11 25, which is composed of $0.5 \mathrm{wt} \%$ acetic acid $+5.0 \mathrm{wt} \% \mathrm{NaCl}$. Before corrosion test, the electrolyte was purged with $\mathrm{N}_{2}$ (Fume Hood CVD100 Vidy) in a separated recipient during $1 \mathrm{~h}$, then this solution was poured into the electrochemical cell (already with the electrodes positioned) and further degassed for $15 \mathrm{~min}$. Thereafter, $\mathrm{H}_{2} \mathrm{~S}$

Table 1. Characteristics of the API 5L steel tubes.

\begin{tabular}{lccc}
\hline IDENTIFICATION & DIMENSIONS & $(\mathrm{mm})$ & Rockwell \\
\hline & Diameter & Thickness & Hardness \\
\hline API 5L X65 & 813 & 21 & 183 \\
API 5L X 80 & 508 & 20 & 294 \\
\hline
\end{tabular}

gas was bubbled (Fume Hood CVD100 Vidy) at a rate of approximately $200 \mathrm{ml}$ per minute during $1 \mathrm{~h}$. Experiments without $\mathrm{H}_{2} \mathrm{~S}$ saturation were also performed.

The working electrodes (WE) were cut from the crosssection of the tubes (ASTM G106 -89 (2004) standard ${ }^{24}$ ), embedded in bakelite (exposed area $1 \mathrm{~cm}^{2}$ ) and them ground (Sultrade-Struers) up to \# 1200 with silicon carbide emery paper.

The experiments were carried out using two different methodologies. In the first one, denominated when necessary as Procedure $1(\mathrm{P} 1)$, performed either in deaerated or in $\mathrm{H}_{2} \mathrm{~S}$ saturated solution, initially, the open circuit potential (OCP) was monitored for $1 \mathrm{~h}$, period necessary to acquire a constant value, followed by the electrochemical impedance spectroscopy (EIS) and potentiodynamic polarization (PDP) tests, this latter after supplementary 15 minutes stabilization of the OCP. Due to the deaeration procedure, in the experiments performed in the deaerated solution the OCP monitoring was initiated after 15 minutes immersion of the WE in the test solution (after the supplementary 15 min $\mathrm{N}_{2}$ purging), whereas in the $\mathrm{H}_{2} \mathrm{~S}$ saturated solution the previous immersion period was 75 minutes, as $\mathrm{N}_{2}$ purging was followed by $1 \mathrm{~h} \mathrm{H}_{2} \mathrm{~S}$ bubbling.

In the second procedure, performed only in $\mathrm{H}_{2} \mathrm{~S}$ saturated solution and designated, when necessary, as Procedure 2 (P2), after degassing as described in the previous paragraph, the electrodes remained immersed in the test solution for $24 \mathrm{~h}$, during which the OCP and the EIS behavior were monitored, some samples were submitted to PDP experiments as the final step. SEM and OM observations after corrosion were performed only in these electrodes.

The EIS experiments were carried out using a perturbation amplitude of $10 \mathrm{mV}(\mathrm{rms})$ in the frequency range from $10^{5}$ to $10^{-2} \mathrm{~Hz}$. The acquisition rate was 10 points per decade. The PDP tests were performed from - $250 \mathrm{mV}$ vs OCP to $+250 \mathrm{mV}$ vs OCP at a scan rate of $1 \mathrm{mV} / \mathrm{s}$. A minimum of three tests was performed for each condition.

All the experiments were accomplished with a $\mu$ AUTOLAB type II potentiostat equipped with a frequency response analyzer (FRA2) module using a conventional three electrode system, with a Saturated Calomel Electrode (SCE) as reference, a platinum wire counter electrode and the X65 and X80 steel as WE.

\subsection{Hydrogen Induced Cracking (HIC) experiments}

These tests were carried out in $\mathrm{H}_{2} \mathrm{~S}$-saturated A solution $(0.5 \%$ acetic acid (wt) $+5.0 \% \mathrm{NaCl}(\mathrm{wt}))$ and followed the recommendations of NACE TM0284-1125. Samples were

Table 2. Chemical composition of the API 5L X65 and X80 steel (wt.\%).

\begin{tabular}{cccccccccccc}
\hline Steel & $\mathrm{C}$ & $\mathrm{Mn}$ & $\mathrm{Si}$ & $\mathrm{S}$ & $\mathrm{P}$ & $\mathrm{Ni}$ & $\mathrm{Cu}$ & $\mathrm{Cr}$ & $\mathrm{Al}$ & $\mathrm{Nb}$ & $\mathrm{V}+\mathrm{Ti}$ \\
\hline $\mathbf{X 6 5}$ & 0.04 & 1.37 & 0.35 & 0.001 & 0.009 & 0.06 & 0.05 & 0.03 & 0.04 & 0.05 & 0.02 \\
$\mathbf{X 8 0}$ & 0.07 & 1.79 & 0.33 & 0.001 & 0.012 & 0.002 & 0.013 & 0.164 & 0.0035 & 0.04 & 0.0017 \\
\hline
\end{tabular}


extracted from the rolling direction with $(100 \pm 1) \mathrm{mm}$ length and $(20 \pm 1) \mathrm{mm}$ width, whereas the thicknesses corresponded to those of the original pipelines. Before testing, the samples were machined with a milling machine and ground (\#320 - Aerotex Aropol 2V) using water as lubricant until completely flat surfaces were obtained. Then, they were thoroughly washed with ethanol dried in a hot air stream and placed in the test vessel so that the specimens did not touch either each other or the vessel walls, according to the NACE TM0284-1126 recomendations.

To perform the test, the electrolyte was initially degassed with $\mathrm{N}_{2}$ during one hour and then poured $(5 \mathrm{~L})$ into the testing vessel, where the samples were already positioned. Then supplementary $\mathrm{N}_{2}$ degassing (15 min) was performed followed by $1 \mathrm{~h} \mathrm{H}_{2} \mathrm{~S}$ saturation $\left(200 \mathrm{ml} / \mathrm{min} / \mathrm{L}^{26}\right)$. The total test duration was $96 \mathrm{~h}\left((25 \pm 3){ }^{\circ} \mathrm{C}\right)$ computed immediately after the 60 -minute $\mathrm{H}_{2} \mathrm{~S}$ injection period. ${ }^{19}$

After the HIC test, the samples were withdrawn from the vessel, thoroughly washed with soap and water, washed with ethanol, dried in a hot air stream and sectioned with an ISOMET precision cutter with diamond. Afterwards, the sections were embedded in bakelite with the cross sections facing upwards, ground up to \#1200 emery paper (Arotec Aropol 2V), polished with diamond paste down to $1 \mu \mathrm{m}$ (Sultrade, Struers) and then observed for crack initiation and propagation by OM (Olympus BX60M) and SEM (Olympus
Philips XL-30) without and with Nital ( $\mathrm{HNO}_{3} 2 \%+100 \mathrm{ml}$ ethanol, $10 \mathrm{~s}$ ) etching.

\section{Results}

\subsection{Analysis of inclusions and microstructural characterization}

Figure 1 (a) shows an OM image of the surface of the API 5L X65 steel after polishing and without etching. A uniform distribution of round-shaped inclusions was verified (SEM image insert in the Figure), which analyzes by EDS (Figure 1 (b)) showed mainly the presence of $\mathrm{Ca}$, $\mathrm{Al}, \mathrm{Mg}$ and Ti. Their mean size were between 1.8 and 6.4 $\mu \mathrm{m}$, allowing to classify them as globular-oxide-sulfide fine series (D-Globular Oxide/Sulfide Type and Thin subcategory) according to ASTM E45 (2013) ${ }^{23}$.

API 5L X80 steel also presented evenly distributed inclusions, however with higher density (Figure 2 (a)) and several of them with irregular shape (Insert of Figure 2 (a)). Regarding the composition of the inclusions in this material, the EDS analysis (Figure 2 (b)) indicated the presence of $\mathrm{Al}, \mathrm{O}, \mathrm{S}$ and $\mathrm{Mn}$. Their mean size were between 2.8 and $9.2 \mu \mathrm{m}$, allowing to classify them as D-globular oxide-sulfide heavy series (D-Globular Oxide/Sulfide Type and Heavy subcategory) according to ASTM E45 (2013) ${ }^{23}$.

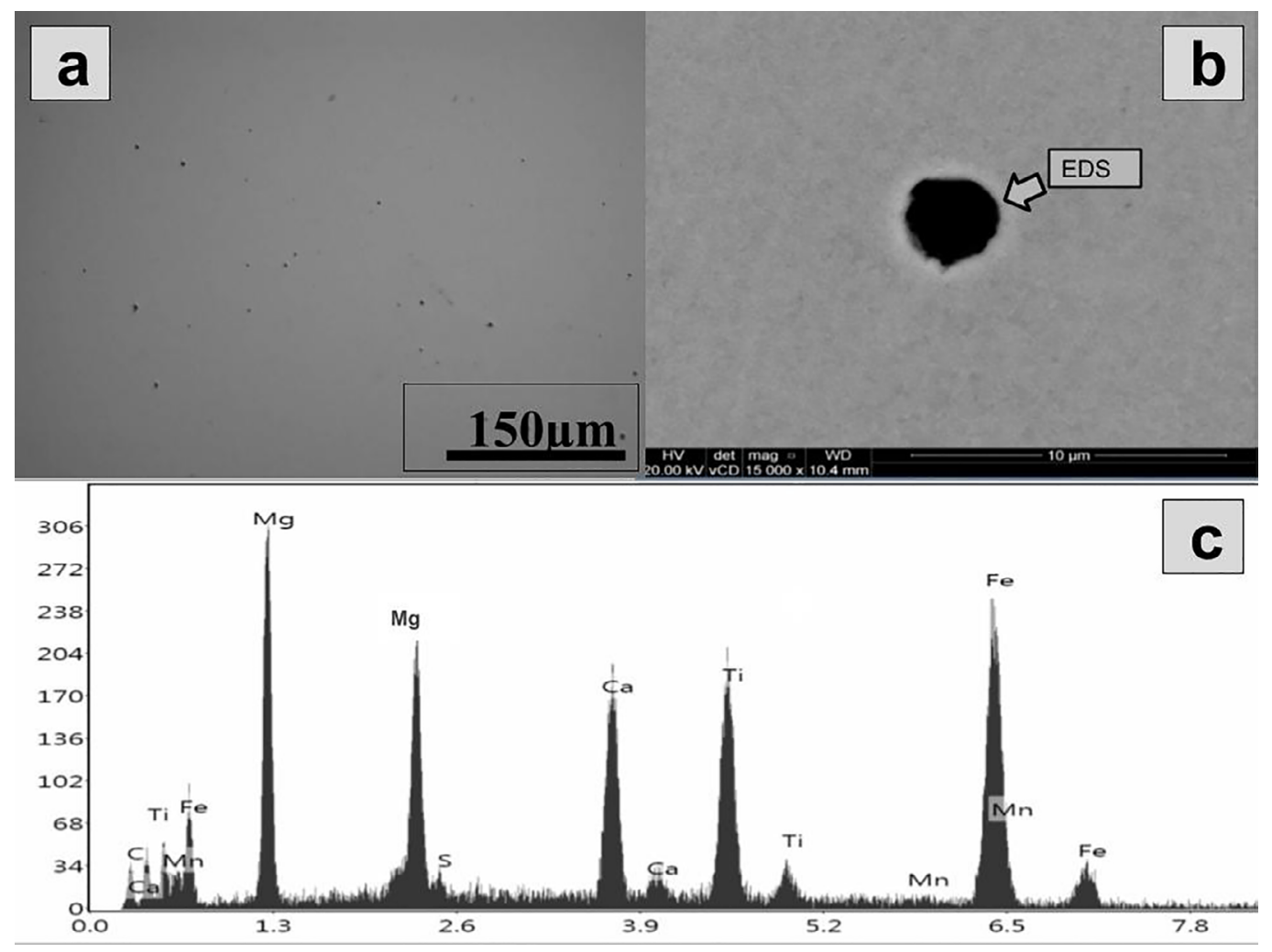

Figure 1. Optical microscopy image of the inclusions distribution in the microstructure of the API 5L X65 steel (a), representative EDS spectrum of the inclusions (b), and backscattered SEM image of a round-shaped inclusion (insert in (a)) 
The analysis of the microstructure of the API 5L X65 steel by OM after etching with $2 \%$ Nital reagent (Figure 3 (a)) presented uniform microstructure with refined grains, without the presence of banding. SEM image (Figure 3 (b)) showed a ferritic matrix with pearlite grains (indicated by the arrow) dispersed in the matrix. The mean grain size determined according to ASTM E112-13(2014) 22 was $6.5 \pm 0.3 \mu \mathrm{m}$, with acicular shape.
The microstructure of the API 5L X80 steel is formed by uniform and refined ferrite grains (Figure 4 (a)). SEM analysis (Figure 4 (b)) showed no banding and revealed a ferritic matrix, with minimal presence of M/A (martensite/ austenite) microconstituents at the grain boundaries. The average grain size was $4.6 \pm 0.3 \mu \mathrm{m}$ with polygonal grain contours.

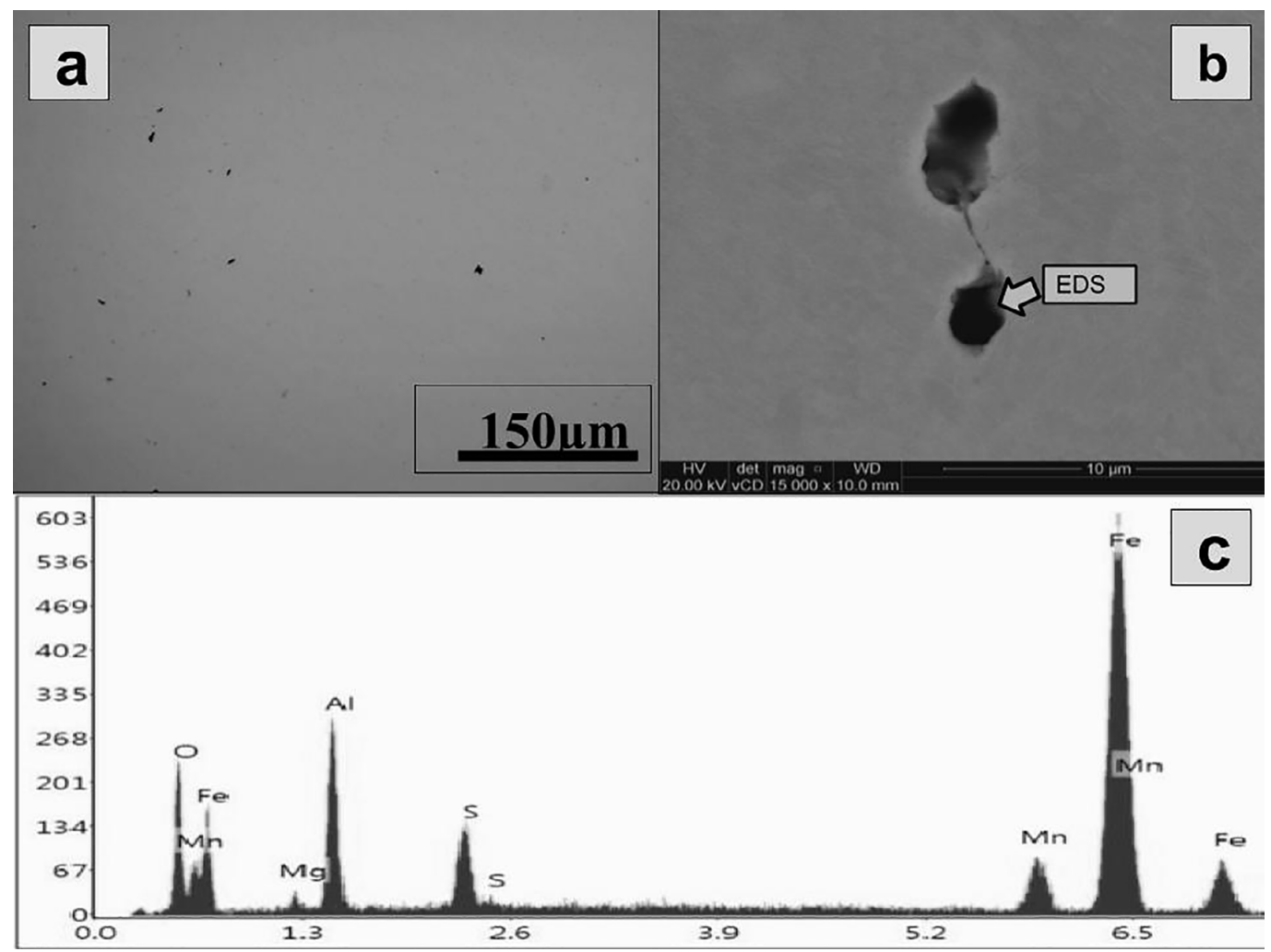

Figure 2. Optical microscopy image of the inclusions distribution in the microstructure of the API 5L X80 steel (a), representative EDS spectrum of the inclusions (b), and backscattered SEM image of an irregular-shaped inclusion (insert in (a)).

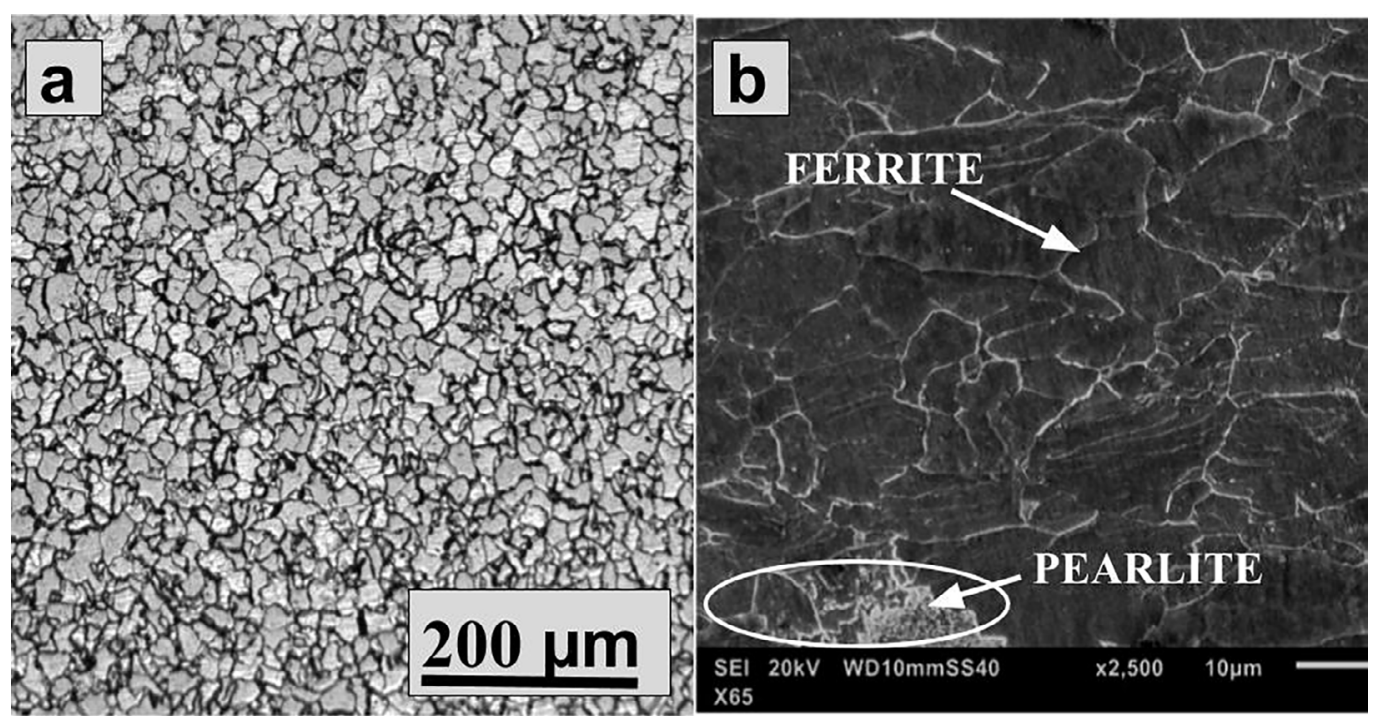

Figure 3. (a) Optical microscopy and (b) SEM (secondary electrons) image of the API 5L X65 steel. Images from the central cross-section to the rolling direction. Nital $2 \%$ etched. 


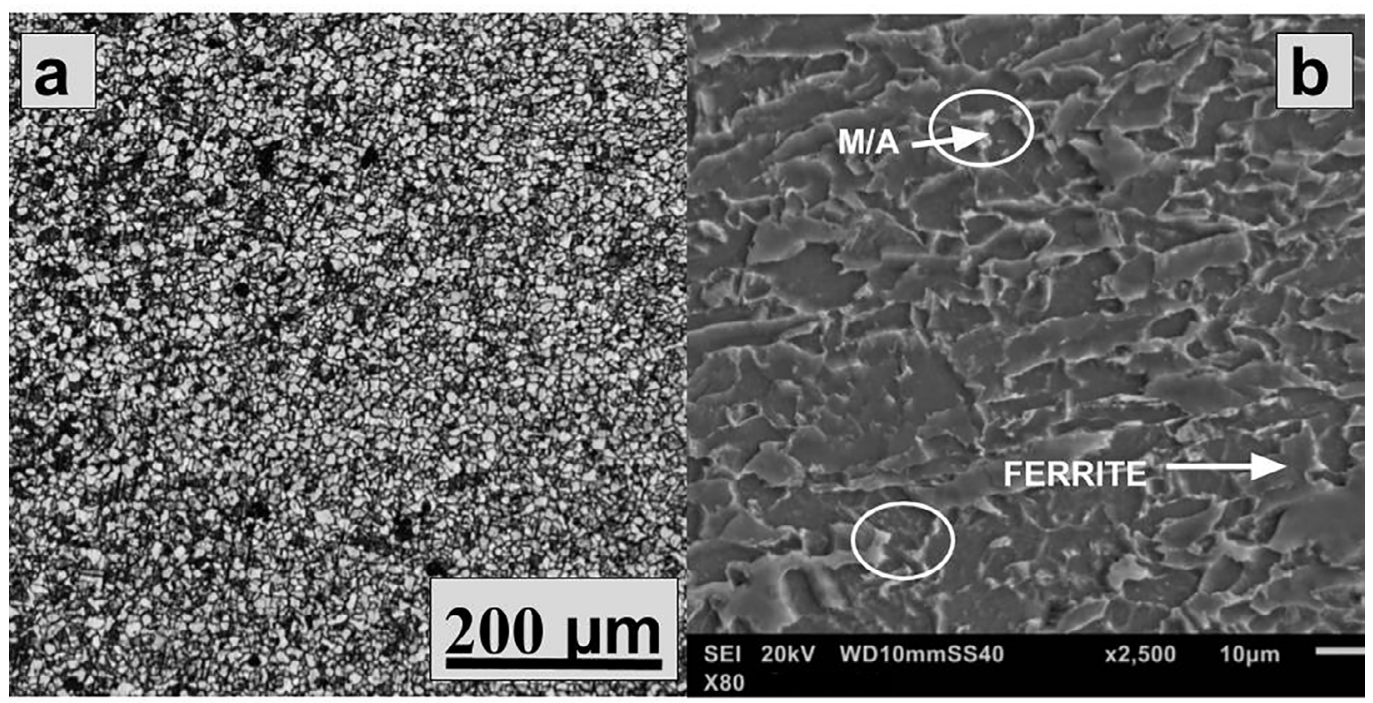

Figure 4. (a) Optical microscopy and (b) SEM (secondary electrons) image of the API 5L X80 steel. Images from the central cross-section to the rolling direction. Nital $2 \%$ etched.

\subsection{Electrochemical tests}

\subsubsection{Electrochemical behavior - deaerated and $\mathrm{H}_{2} \mathrm{~S}$ saturated solution - Procedure 1}

Figure 5 (a) shows the OCP variation of the two steels during 2000s immersion in deaerated solution A without and with saturation with $\mathrm{H}_{2} \mathrm{~S}$. For all conditions, a fast potential stabilization was observed, which can be a consequence of the period the samples remained immersed in the test electrolyte during the degassing procedure prior to $\mathrm{OCP}$ registration. In addition, for the two steels, there is a decrease of the OCP in the $\mathrm{H}_{2} \mathrm{~S}$ saturated condition and the OCP of the API 5L X80 steel is always lower when compared with the API 5L X65 one.

EIS diagrams (Figure 6) for the two steels in both media are composed of one highly depressed capacitive loop whose corresponding phase angles are quite broad, indicating time constants overlapping. In accordance with published studies $^{26-27}$, the results show a visible decrease of the impedance in the $\mathrm{H}_{2} \mathrm{~S}$ saturated medium, confirming its higher aggressiveness. Furthermore, for both conditions, the API 5L X80 steel presented lower impedance values. The characteristics of these diagrams indicate that even though with different kinetics, the corrosion mechanism in both media must be similar.

The results of the PDP tests (Figure 7) for the two steels show that the anodic and cathodic reactions are controlled by activation. In addition, and in accorddance with the results of the EIS tests, it is observed that the API 5L X80 steel presents, for both conditions, greater susceptibility to corrosion, characterized by more depolarized anodic and cathodic curves and higher corrosion current densities. The data presented in Table 3, obtained by Tafel extrapolation, are consistent with these findings. The corrosion current

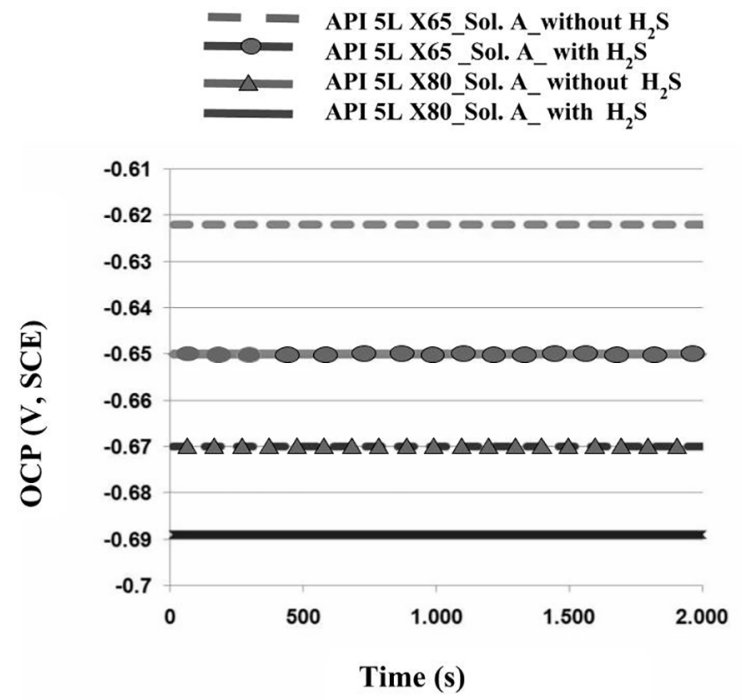

Figure 5. OCP variation for the API 5L X65 and API 5L X80 steels in deaerated solution A, NACE TM0284 (2011), without and with $\mathrm{H}_{2} \mathrm{~S}$ saturation. Experimental Procedure 1.

densities $\left(\mathrm{i}_{\text {corr }} \mathrm{mA} / \mathrm{cm}^{2}\right)$ can be sorted in descending order as: $\mathrm{X} 80$ with $\mathrm{H}_{2} \mathrm{~S}>\mathrm{X} 65$ with $\mathrm{H}_{2} \mathrm{~S}>\mathrm{X} 80$ without $\mathrm{H}_{2} \mathrm{~S}>\mathrm{X} 65$ without $\mathrm{H}_{2} \mathrm{~S}$. For both materials, extrapolated $\mathrm{i}_{\text {corr }}$ values were about one order of magnitude higher in the $\mathrm{H}_{2} \mathrm{~S}$ saturated electrolyte, which is in accordance with the expected higher aggressiveness of the sour medium ${ }^{28-33}$. On the other hand, for the same electrolyte, the $i_{\text {corr }}$ slightly increased for the X80 steel when comparing with the X65.

\subsubsection{Electrochemical behavior in $\mathrm{H}_{2} \mathrm{~S}$ saturated solution (24h) - sour medium - Procedure 2}

For the $\mathrm{H}_{2} \mathrm{~S}$-saturated medium, sour medium, the corrosion of the two steels during $24 \mathrm{~h}$ of immersion was investigated. 

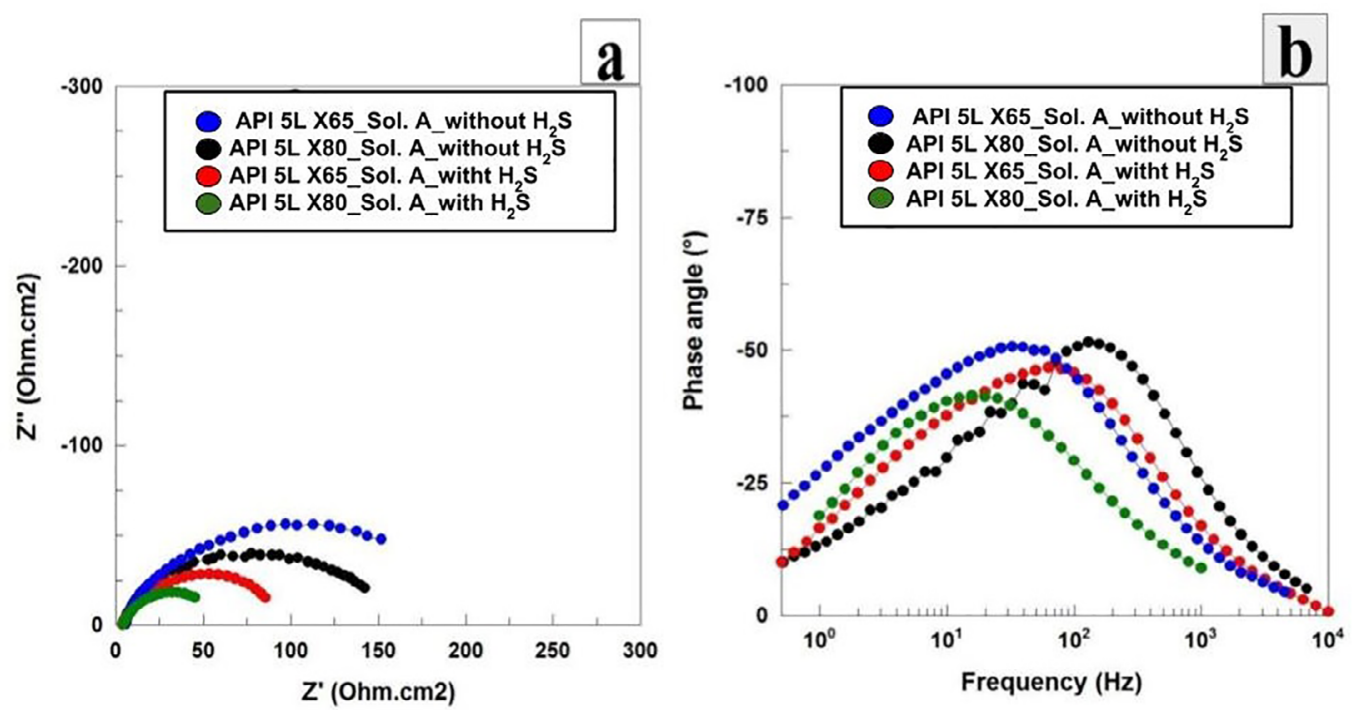

Figure 6. Nyquist (a) and phase angle (b) diagrams of API 5L X65 and API 5L X80 steels in deaerated solution A, NACE TM0284 (2011), without and with $\mathrm{H}_{2} \mathrm{~S}$ saturation. Experimental Procedure 1.

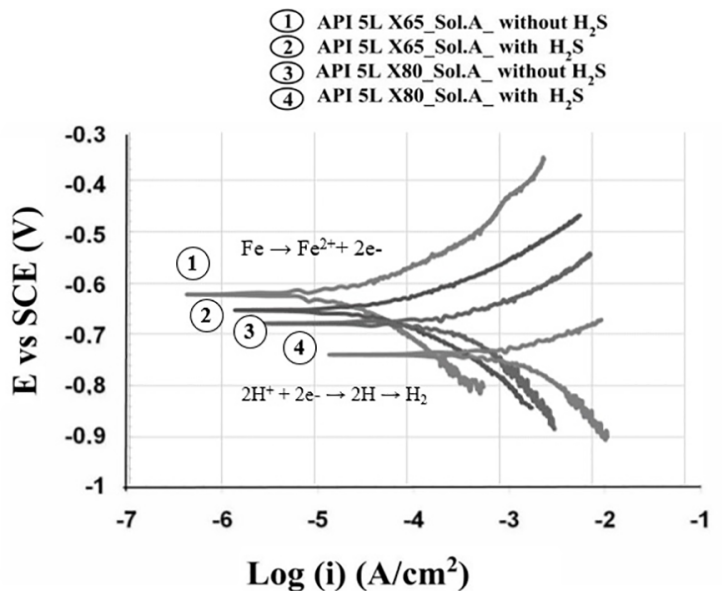

Figure 7. Potentiodynamic polarization curves for API 5L X65 and API 5L X80 steels in deaerated solution A, NACE TM0284 (2011), without and with $\mathrm{H}_{2} \mathrm{~S}$ saturation. Experimental Procedure 1.

Figure 8 shows that, for the two steels, the OCP remains stable throughout the test period, indicating that there is no alteration of the interfacial processes. It is also noted that the API 5L X80 steel has lower OCP at any time.

In the EIS experiments (Figures 9 and 10) the characteristics of the diagrams remained the same as those observed in the short duration tests, without modifications in their shapes, further indicating that no change in the reactions mechanism take place. However, for both materials, an

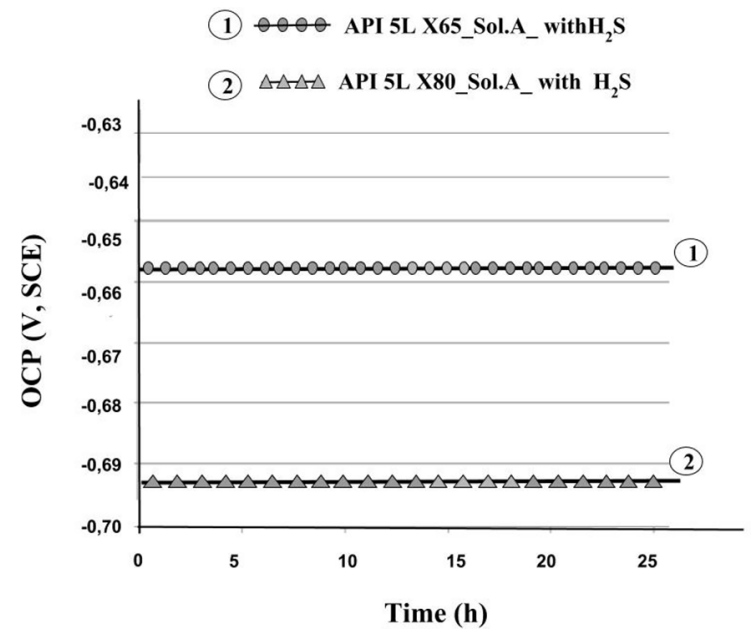

Figure 8. OCP variation for the API 5L X65 and API 5L X80 steels during $24 \mathrm{~h}$ immersion in deaerated solution A, NACE TM0284 (2011), saturated with $\mathrm{H}_{2} \mathrm{~S}$, sour medium. Procedure 2 .

increase in impedance is observed as a function of immersion time, indicating a decrease in the intensity of the corrosive attack. Random decreases followed by continued increase in the impedance values were observed during the whole test period. The corrosion process of iron and steel in sour medium is generally accompanied by iron sulfide film formation, therefore, the observed behavior can be attributed to film growth until a maximum thickness is reached, when

Table 3. Table with information extracted from the polarization curves of Figure 7. Procedure 1.

\begin{tabular}{lccccc}
\hline Material & Condition & EcorrV vs. SCE & ba V dec. ${ }^{-1}$ & bc V dec. ${ }^{-1}$ & $\mathrm{i}_{\text {corr }} \cdot\left(\right.$ A.cm cm $\left.^{-2}\right)$ \\
\hline X65 steel & Without $\mathrm{H}_{2} \mathrm{~S}$ & -0.623 & 0.019 & 0.060 & $1.17 \times 10^{-5}$ \\
X65 steel & With $\mathrm{H}_{2} \mathrm{~S}$ & -0.648 & 0.019 & 0.060 & $1.98 \times 10^{-4}$ \\
X80 steel & Without $\mathrm{H}_{2} \mathrm{~S}$ & -0.686 & 0.019 & 0.060 & $2.34 \times 10^{-5}$ \\
X80 steel & With $\mathrm{H}_{2} \mathrm{~S}$ & -0.758 & 0.019 & 0.060 & $2.76 \times 10^{-4}$ \\
\hline
\end{tabular}



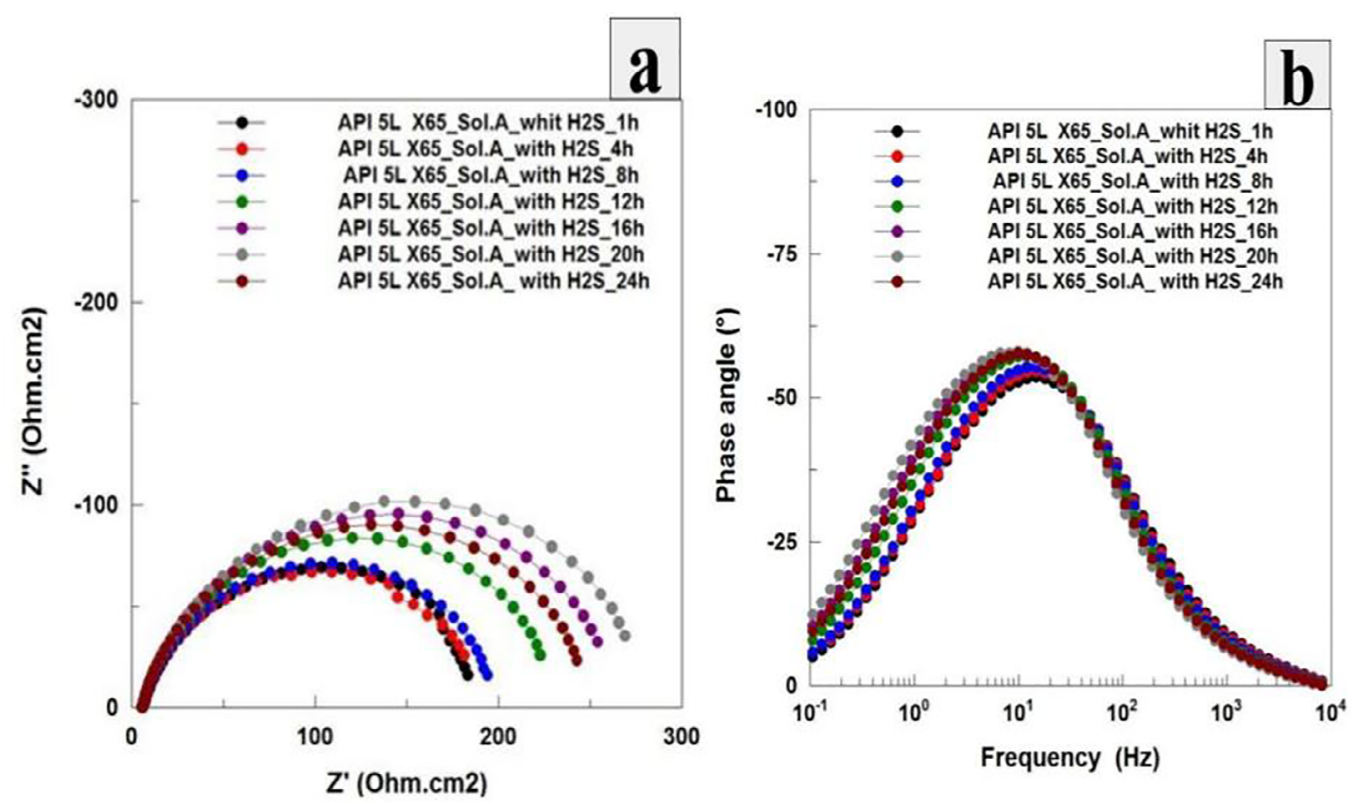

Figure 9. Nyquist (a) and phase angle (b) diagrams for the API 5L X65 steel during 24h immersion in deaerated solution A, NACE TM0284 (2011), saturated with $\mathrm{H}_{2} \mathrm{~S}$, sour medium. Procedure 2.
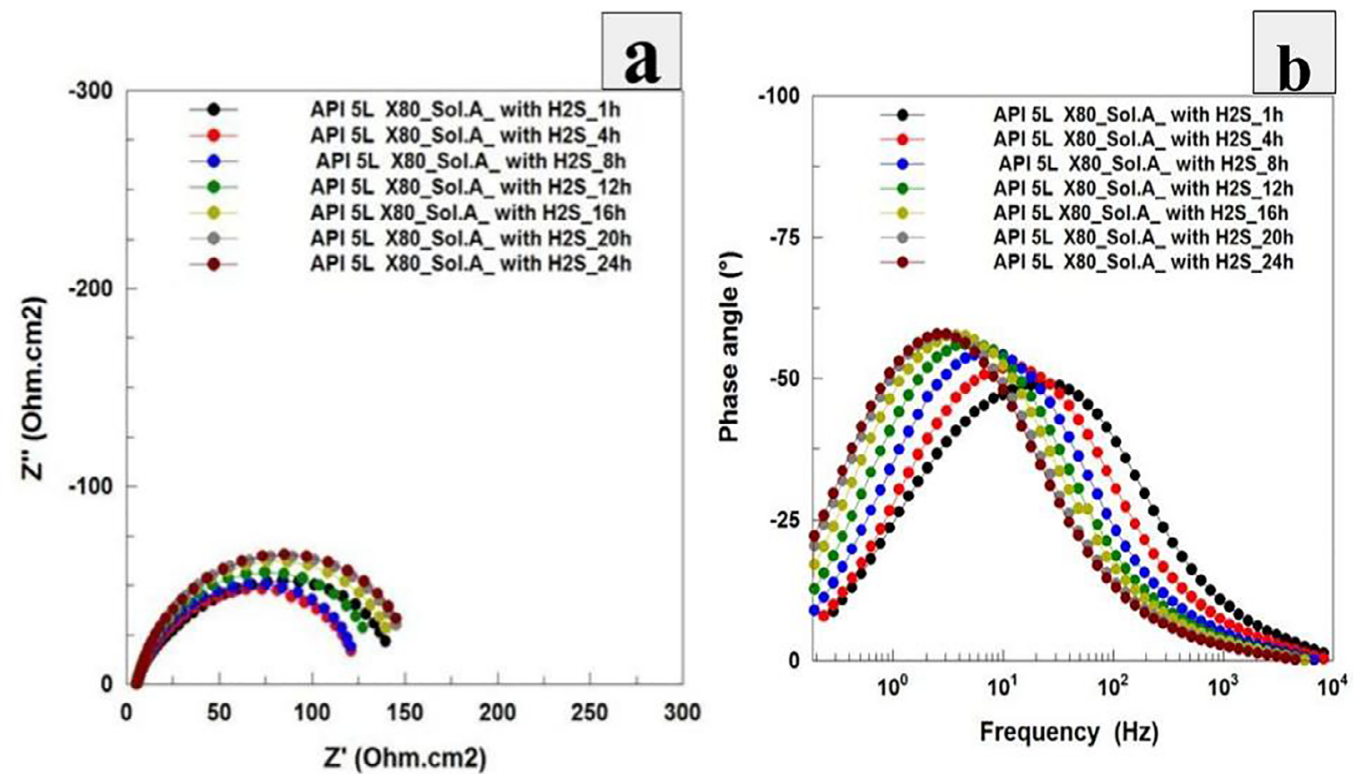

Figure 10. Nyquist (a) and phase angle (b) diagrams for the API 5L API 5L X80 steel during 24h immersion in deaerated solution A, NACE TM0284 (2011), saturated with $\mathrm{H}_{2} \mathrm{~S}$, sour medium. Procedure 2.

film detachment occurs (confirmed by the presence of a black precipitate deposited at the cell bottom), initiating an intermitent process of growth and detachment. ${ }^{28-30}$

The comparison between the EIS diagrams of Figures 9 and 10 , presented in the same scale, clearly shows that the API 5L X80 steel (Figure 10) is less corrosion resistant. In addition, for this steel, the phase angle diagrams are slightly more deformed in the high frequency domain, indicating a possible difference in the corrosion mechanism.
In agreement with the other electrochemical tests, the PDP curves obtained after $24 \mathrm{~h}$ of immersion (Figure 11) presented the same characteristics of those observed after $1 \mathrm{~h}$ of test, confirming that there is no change in the reaction mechanism. However, for this condition, it turns out clear that the API 5L X80 steel presents higher corrosion current density caused by depolarization of the anodic curve, which is confirmed by the Tafel extrapolation results presented in Table 4 showing a slight higher $i_{\text {corr }}$ for this steel. On the other 


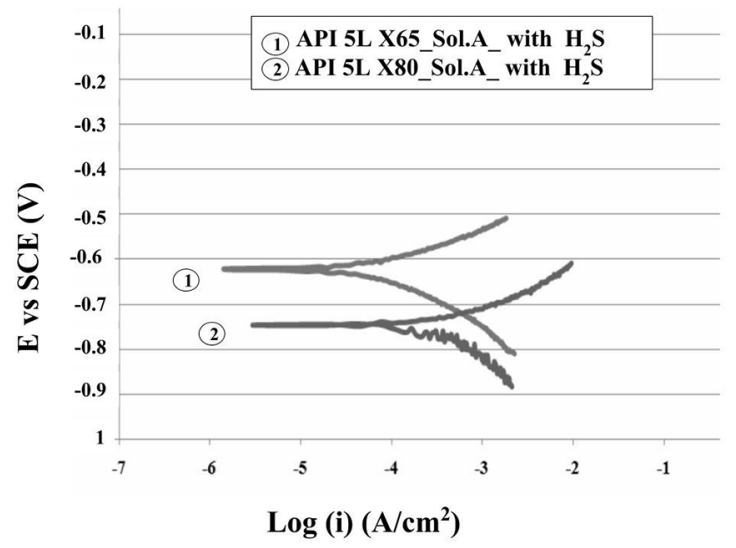

Figure 11. Potentiodynamic polarization curves for the API 5L X65 and API 5L X80 steels after 24h immersion in deaerated solution A, NACE TM0284 (2011), saturated with $\mathrm{H}_{2} \mathrm{~S}$, sour medium. In the diagrams the main anodic and cathodic reactions are indicated. Procedure 2.

Table 4. Table with information extracted from the polarization curves after $24 \mathrm{~h}$ of immersion, Figure 11. Procedure 2.

\begin{tabular}{lccccc}
\hline & Condition & $\begin{array}{c}\text { EcorrV } \\
\text { vs. } \\
\text { SCE }\end{array}$ & $\begin{array}{c}\text { ba V } \\
\text { dec. } .^{-1}\end{array}$ & $\begin{array}{c}\text { bcV } \\
\text { dec. }^{-1}\end{array}$ & $\begin{array}{c}\text { icorr } \\
\left(\text { A.cm }^{-2}\right)\end{array}$ \\
\hline X65 steel & With $\mathrm{H}_{2} \mathrm{~S}$ & -0.632 & 0.018 & 0.059 & $\begin{array}{c}2.26 \mathrm{x} \\
10^{-5}\end{array}$ \\
X80 steel & With $\mathrm{H}_{2} \mathrm{~S}$ & -0.763 & 0.018 & 0.059 & $\begin{array}{c}3.08 \mathrm{x} \\
10^{-5}\end{array}$ \\
\hline
\end{tabular}

hand, in accordance with the EIS results, the comparison of the $i_{\text {corr }}$ values in Tables 3 and 4 indicates that there was a slight decrease of the corrosion process.

\subsubsection{Microstructural characterization after $24 \mathrm{~h}$ immersion in $\mathrm{H}_{2} \mathrm{~S}$-saturated solution - sour medium - Procedure 2}

Figure 12 shows micrographs by OM (Figure 12 (a)) and SEM (Figure 12 (b)) of the surface of the API 5L X65 steel after $24 \mathrm{~h}$ of immersion in the sour medium. The material presented generalized attack, characterized by the formation of a thick layer of corrosion products, which, nevertheless, was detached during the sample preparation for microscopic observation. Also, localized attacks were observed, which, however, did not develop deep pits. The corrosion products formed in the regions where localized attack took place presented globular shapes (Figure 12 (c)), and their EDS analyzes (Figure 12 (d)) showed the presence of $\mathrm{O}, \mathrm{Fe}, \mathrm{S}$, and $\mathrm{Ca}$ indicating to be associated with the presence of inclusions.

Figure 13 displays the OM (Figure 13(a)) and SEM (Figure 13(b)) micrographs of the API 5L X80 steel after 24h immersion in the sour medium, whereas Figures 13(c) and (d) present, respectively, the magnified SEM images of the corrosion products formed above a localized corrosion site and its EDS analysis. The micrographs and analysis show the same features as already presented for the API 51 $\mathrm{X} 65$ steel, with the difference that the localized corrosion is more intense in this material (pits are more numerous and deeper). Also for this sample a thick corrosion product layer was formed, which detached during sample preparation for microscopic analysis.

\subsection{Hydrogen Induced Cracking (HIC) tests}

HIC tests were performed according to NACE TM 0284-2011 ${ }^{19}$ standard using solution A saturated with $\mathrm{H}_{2} \mathrm{~S}$. Due to the aggressiveness of the sour medium, $\mathrm{H}_{2}$ evolution at the samples surface was observed during the whole duration of the test ( $96 \mathrm{~h}$ ), indicating intense corrosion. The crosssection observations after polishing of the API 5L X65 steel by OM (Figure 14(a)) and SEM (Figure 14(b)) did not reveal signs of cracks nucleation or propagation. On the other hand, the API 5L X80 steel presented a deep and large cracks in the central section parallel to the rolling direction (OM in Figure 15(a) and SEM in Figure 15(b)), which was further analyzed by SEM after Nital $2 \%$ etching. SEM image (Figure 15(c)) shows the presence of an inclusion in the crack propagation path, which EDS analysis (Figure 15(d)) showed the presence of Mn and S.

\section{Discussion}

\subsection{Inclusions analysis and microstructural characterization}

The inclusions of the API 5L X65 steel were roundshaped, homogeneously distributed in the matrix and with an average size between 1.8 and $6.4 \mu \mathrm{m}$. On the other hand, for the steel API 5L X80, they were also evenly distributed, but in greater quantity, they were larger (between 2.8 and $9.2 \mu \mathrm{m}$ ), and both round-shaped and irregular inclusions with angular appearance were present. These latter were found mainly in the central regions of the sample, which was supplied as a pipe.

The experimental results showed that the API 5L X80 steel is slightly less resistant to corrosion than API 5L X65 and is also susceptible to HIC. It is a consensus in the literature that inclusions play a central role in these two factors. Initially, they constitute microstructural heterogeneities at which, often, the electrochemical activity differs from the matrix, forming galvanic microcells, serving as points for localized corrosion initiation. In an investigation performed with materials with similar composition to those used in the present study, Hincapie et al. ${ }^{34}$ verified that increased number of inclusions resulted in increased corrosion susceptibility.

Regarding the HIC resistance, inclusions with larger size and irregular shape tend to concentrate stresses, serving as preferential sites for hydrogen accumulation. ${ }^{34-36}$ This relationship between inclusions shape and resistance to HIC of steels is often associated with the existence of 

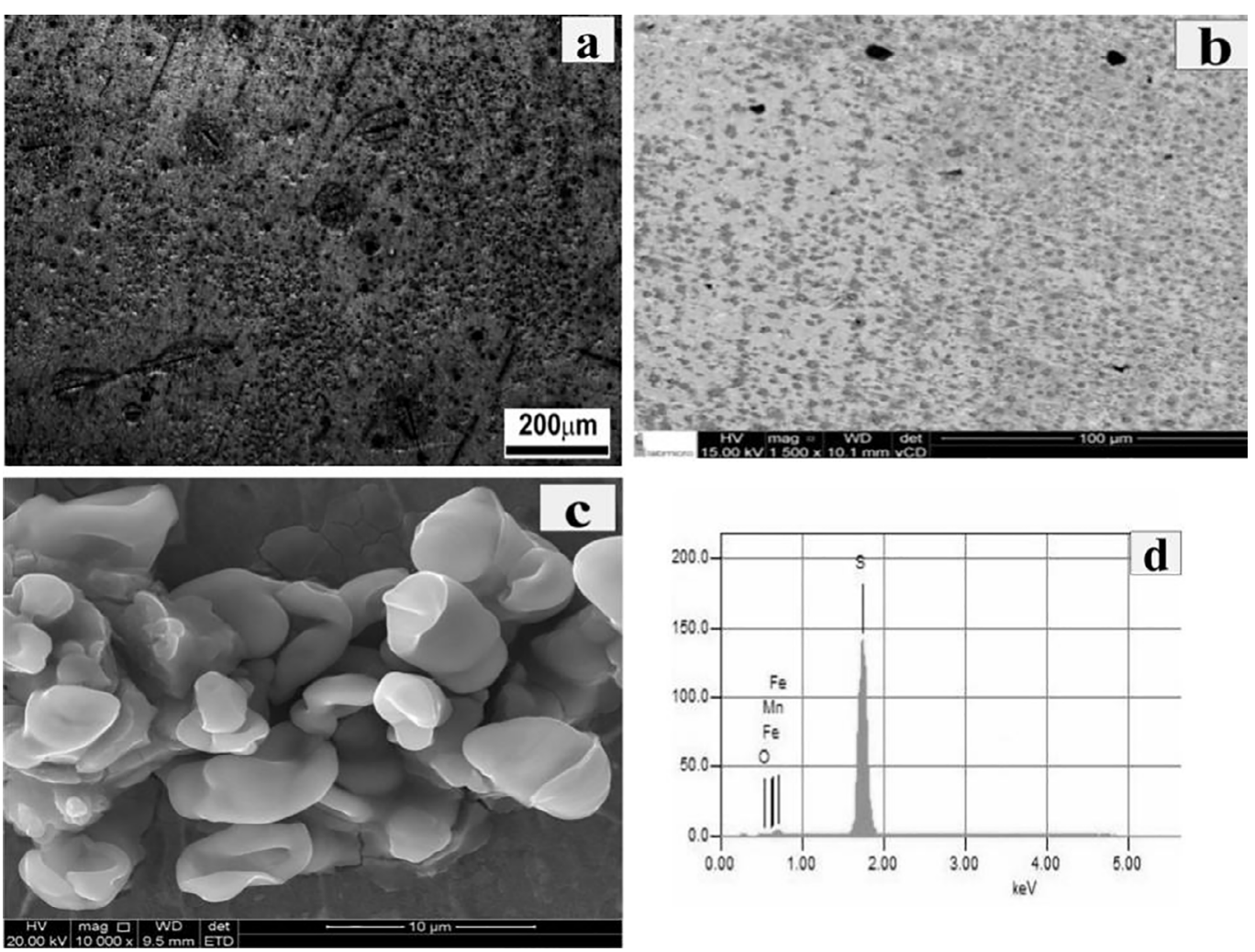

Figure 12. OM (a) and SEM (b) images of the API 5L X65 steel after 24h immersion in deaerated solution A, NACE TM0284 (2011), saturated with $\mathrm{H}_{2} \mathrm{~S}$, sour medium. Magnified SEM image of the corrosion products morphology at the localized corrosion sites (c), EDS analysis of the region depicted in (c) (d).
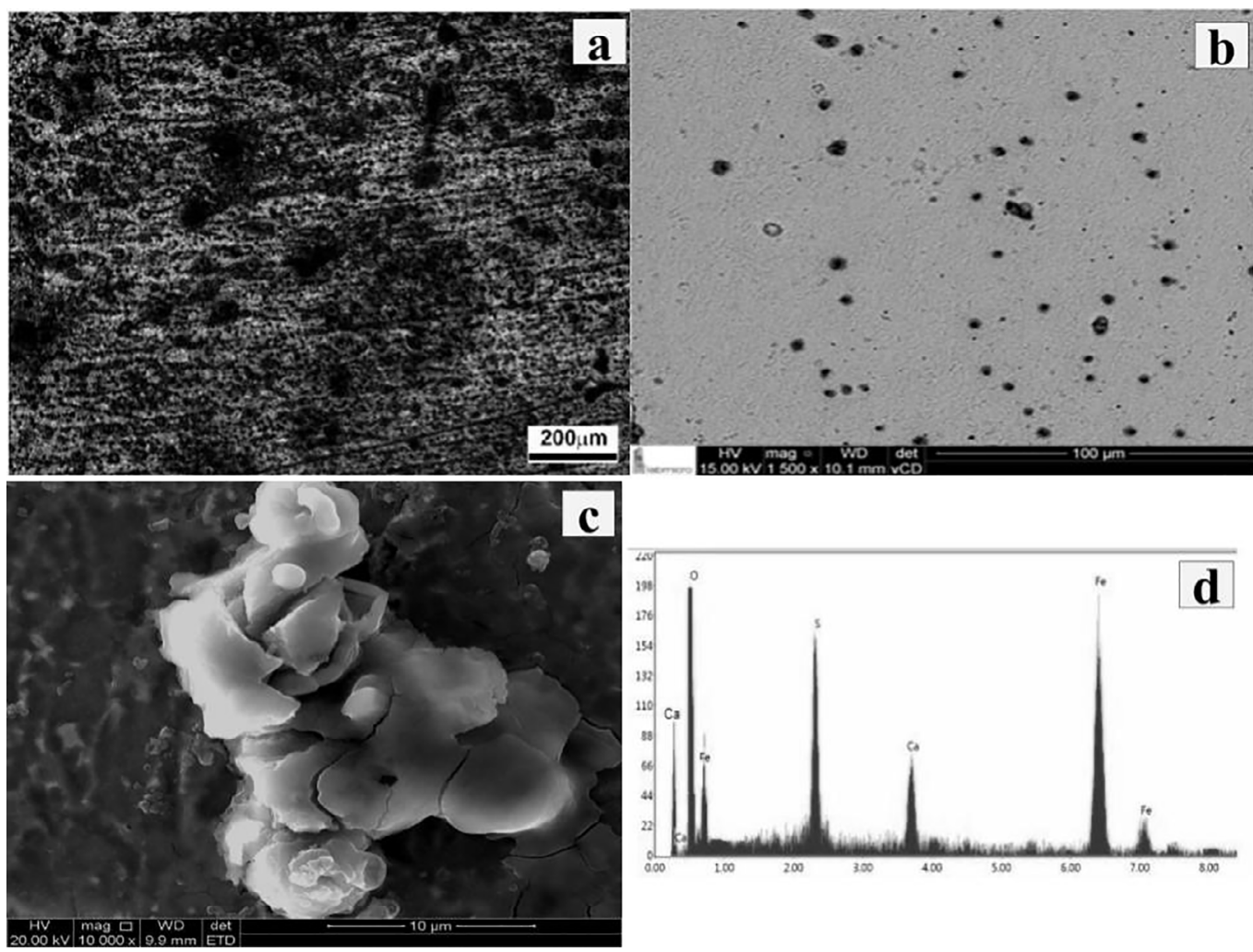

c

Figure 13. OM (a) and SEM (b) images of the API 5L X80 steel after 24h immersion in deaerated solution A, NACE TM0284 (2011), saturated with $\mathrm{H}_{2} \mathrm{~S}$, sour medium. Magnified SEM image of the corrosion products morphology at the localized corrosion sites (c), EDS analysis of the region depicted in (c) (d). 


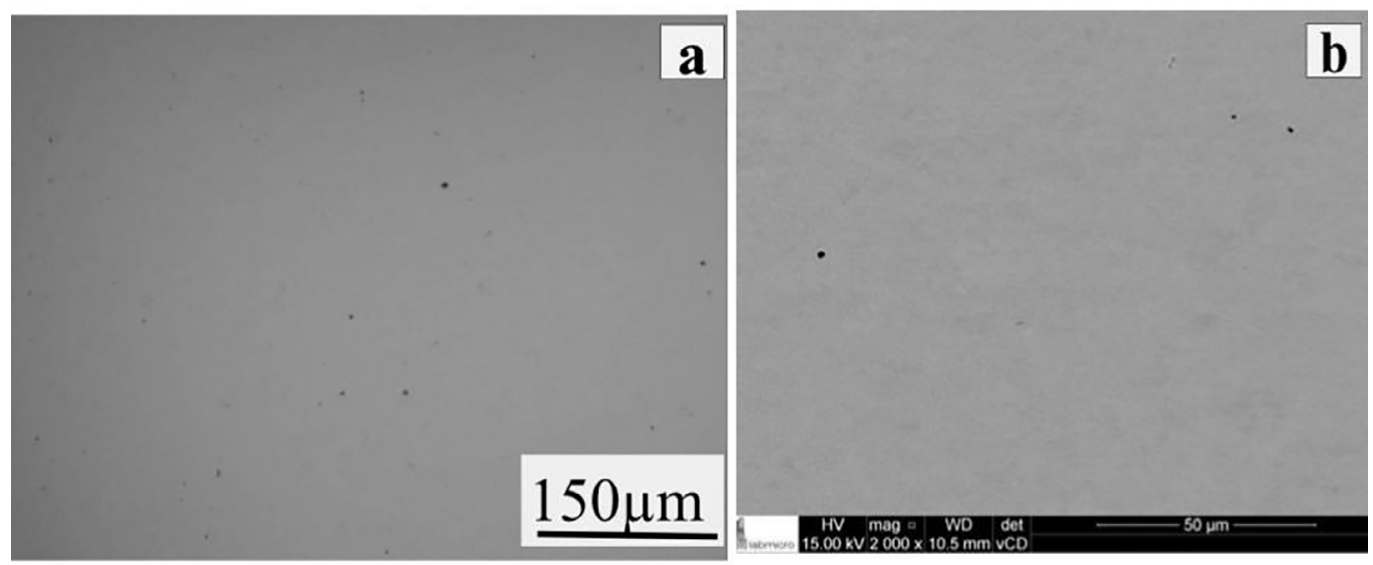

Figure 14. OM (a) and SEM (backscattered electrons) (b) images of one of the API 5L X65 samples submitted to the HIC test. Polished $(1 \mu \mathrm{m})$ cross-section to the rolling direction. Exposure time $96 \mathrm{~h}$ to solution A saturated with $\mathrm{H}_{2} \mathrm{~S}$.

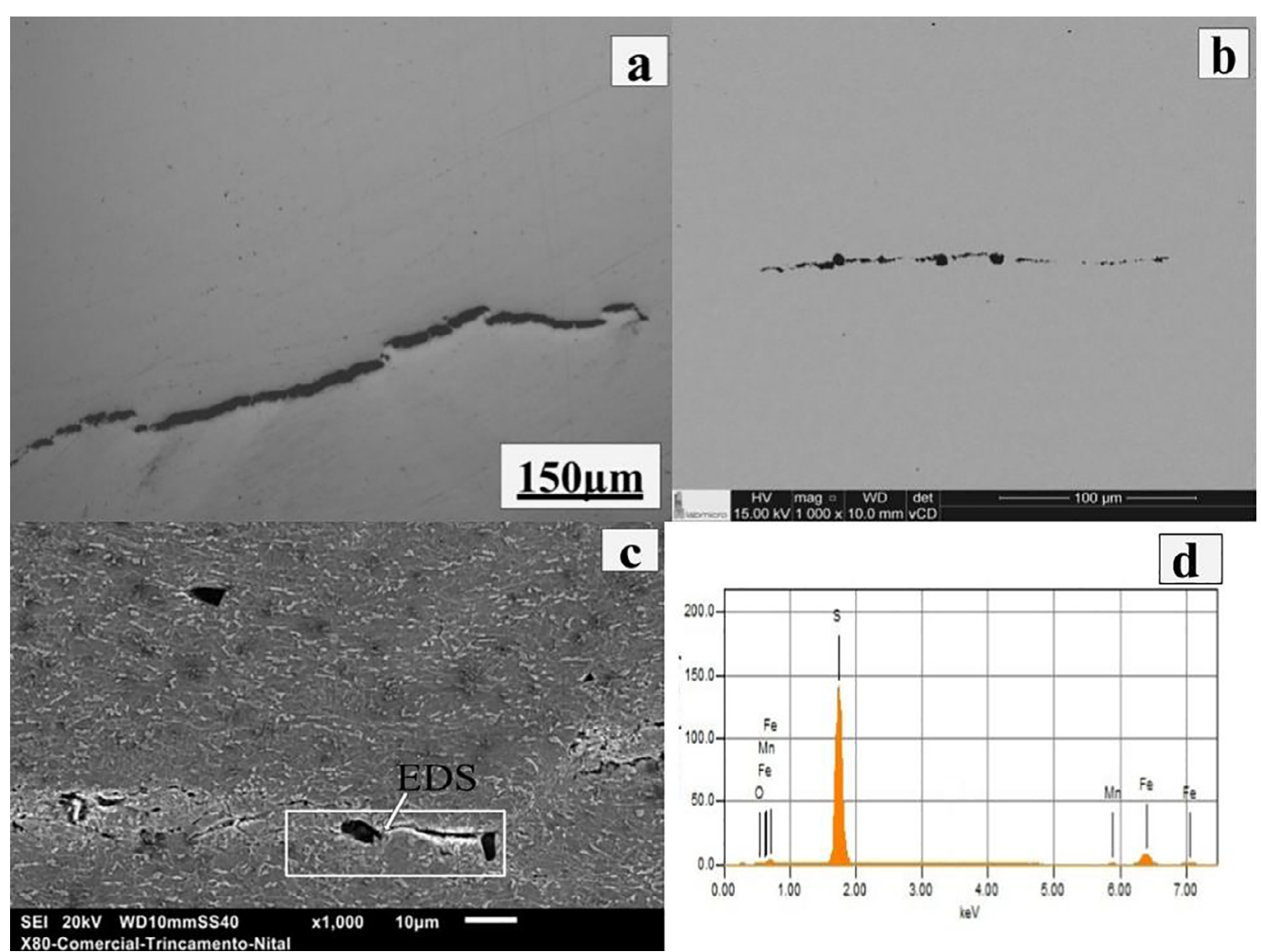

Figure 15. OM (a) and SEM (backscattered electrons) (b) images of one of the API 5L X80 samples submitted to the HIC test. Polished $(1 \mu \mathrm{m})$ cross-section to the rolling direction. Sample after Nital $2 \%$ etching $(\mathrm{c})$, EDS analysis of the inclusion indicated in (c) (d). Exposure time $96 \mathrm{~h}$ to solution A saturated with $\mathrm{H}_{2} \mathrm{~S}$.

microporosities between them and the matrix acting as hydrogen traps ${ }^{35-38}$. Jin, Liu and Cheng ${ }^{36}$ found that the existence of interfacial microporosities between aluminum and silicon oxide inclusions and the matrix of an API 5L X100 steel favored crack nucleation.

The microstructural characterization also showed that the grain size of the API 5L X65 steel was $6.5 \pm 0.3 \mu \mathrm{m}$ and that of the API 5L X80 steel of $4.6 \pm 0.3 \mu \mathrm{m}$. The energy associated with the interaction between grain boundaries and atomic hydrogen is relatively low, ${ }^{36-39 t h e r e f o r e}$, these are considered as reversible traps. As such, they act as temporary sites for atomic hydrogen anchoring, thus serving as a source of hydrogen for irreversible traps. ${ }^{37-38}$ Thus, the smaller grain size of API 5L X80 steel may also contribute to its superior susceptibility to HIC. 


\subsection{Electrochemical tests and corrosion morphology}

The electrochemical tests after short immersion times in deaerated solution A without and with $\mathrm{H}_{2} \mathrm{~S}$ saturation, procedure 1, showed that the OCP of the two steels in sour medium was less noble, and that in this medium they also presented lower impedance. These results are in agreement with those found by several authors using different electrochemical techniques that showed an increase in the corrosion rate of different API steels grades when $\mathrm{H}_{2} \mathrm{~S}$ was added to the electrolytes. ${ }^{27,28,38,40,41,42}$ For the non-sour and the sour medium, the PDP curves (Figure 7) showed that the anodic and cathodic processes are activation-controlled, indicating that these reactions are, respectively, the oxidation of $\mathrm{Fe}$ to $\mathrm{Fe}^{2+}$ and the reduction of $\mathrm{H}^{+}$ions. However, the $\mathrm{pH}$ of solution A practically did not change with saturation with $\mathrm{H}_{2} \mathrm{~S}(2.7 \pm 0.3)$ indicating that the increase in the corrosion rate is a consequence of the acceleration of the kinetics of the anodic reaction, although this aspect is not evident from the comparison between the curves shown in Figure 7.

For all the investigated conditions the impedance diagrams (Figures 6, 9 and 10) presented a single depressed capacitive loop associated with a wide phase angle. This indicates the overlap of more than one time constant, similar to that found by different authors for HSLA steels in sour media with different compositions. . $6,27,28,30,40^{2}$

The shapes both of the EIS diagrams and of the polarization curves were similar in the deaerated and in the $\mathrm{H}_{2} \mathrm{~S}$ saturated solution indicating similar corrosion mechanisms. The monitoring of the corrosion behavior as a function of immersion time in the sour medium, which was performed during $24 \mathrm{~h}$ (Figure 8), showed that, regardless the steel, the OCP remained very stable throughout the test period, indicating that there were no changes in the corrosion mechanism and that the surface modifications resulting from the corrosive process did not alter the interfacial electrochemical processes. Moreover, throughout the period, the OCP of the API 5L X65 steel was more noble. The results of the EIS tests (Figures 9 and 10) showed increased impedance with immersion time, indicating improved corrosion resistance. As reported by different authors for steels immersed in sour medium ${ }^{28,30,40}$ and also observed in the present study, this behavior can be ascribed to the precipitation of a thick dark-colored film of iron sulfide acting as a barrier against diffusion processes. However, due to its low adhesion properties and the electrolyte aggressiveness, although increasing, the impedances continued to be low. In addition, oscillation in the impedance values were verified, ascribed to the detachment of the corrosion products from the electrodes surface.

For all the studied conditions, the electrochemical tests showed that API 5L X80 steel presented lower corrosion resistance than the API 5L X65 steel. Thus, for each specific medium, the impedance modulus was inferior for this former material, which seems to be a consequence of the depolarization of the anodic reaction (Figure 11). However, Tafel extrapolation results, presented in Tables 3 and 4, indicated that, comparing the behavior in the same medium, $i_{\text {corr }}$ is only slightly superior for the X80 steel when compared with the X65. The microstructural characterization (Figures 1 and 2) clearly show higher number of inclusion in the microstructure of the API 5L X80, and this has been already discussed as a source of decreasing corrosion resistance. However, the SEM analysis of the etched microstructures, Figures 3 and 4, revealed the presence of pearlite only in the microstructure of the API 5L X65 steel. It is documented in the literature that a galvanic couple may exist between the cementite (cathodic) and the ferrite (anodic) regions in the lamellar structure of pearlite ${ }^{41}$, this would contribute to enhance the corrosion activity of this latter steel. Therefore, it is hypothesized that while increased number of inclusions contributes to decrease the corrosion resistance of the API $5 \mathrm{~L} \mathrm{X80} \mathrm{steel,} \mathrm{the} \mathrm{presence} \mathrm{of} \mathrm{pearlite} \mathrm{increases} \mathrm{the} \mathrm{corrosion}$ susceptibility of the API 5L X65 steel, explaining why there is only a slight difference between the corrosion behavior of the two materials. Finally, in agreement with all the other experimental results, the Tafel extrapolation procedure showed that, for the two tested materials, a tenfold increase in $i_{\text {corr }}$ was verified when the electrolyte was saturated with $\mathrm{H}_{2} \mathrm{~S}$.

\subsection{Hydrogen Induced Cracking (HIC)}

HIC tests were performed according to the NACE TM 0284-2011 ${ }^{19}$ standard in the solution A saturated with $\mathrm{H}_{2} \mathrm{~S}$. The results showed that the API 5L X65 steel is not susceptible to Hydrogen Induced Cracking (HIC) in the sour gas environment. Thus, neither initiation nor propagation of cracks were detected in the samples submitted to the HIC test. On the other hand, samples of the API 5L X80 steel presented severe cracks in all examined internal surfaces, which were deep and relatively wide in the central and lower parts of the pipe thickness (Figure 15).

As verified in the microstructural characterization, the API 5L X80 steel presented inclusions in greater quantity, some of them with irregular shape, rich in S, Mn. Due to their tendency to accumulate hydrogen and to concentrate stress, ${ }^{6,7,9,10,35}$ inclusions with larger size and irregular shape are detrimental to HIC resistance, as they act like irreversible hydrogen traps serving as points for nucleation of cracks. ${ }^{27-30}$ The SEM observation of the crack (Figure 15) showed the presence of a $\mathrm{MnS}$ inclusion in its propagation pathway, showing that such inclusions can play an important role in the susceptibility to HIC of the investigated API 5L X80 steel. Therefore, due to the low resistance to HIC in media containing $\mathrm{H}_{2} \mathrm{~S}$, X80 steel is still not considered suitable for sour gas application. 


\section{Conclusions}

In the present study, electrochemical techniques and standardized tests (NACE Standard TM 0284-2011) were used to compare the corrosion and HIC resistances of two API 5L steelsone API 5L X65 and the other API 5L X80. The following conclusions can be drawn:

1. The electrochemical tests showed that the two steels investigated showed low corrosion resistance in solution A (NACE TM0284-2011) (5\% sodium chloride $(\mathrm{NaCl})$ and $0.5 \%$ acetic acid $(\mathrm{CH} 3 \mathrm{COOH})$ ), being the performance worsened in sour gas medium.

2. The results also showed that the corrosion resistance of the API 5L X80 steel is slightly inferior to that presented by the API 5L X65, which can be ascribed to the higher number of inclusions in its microstructure. However, its refined and more homogeneous microstructure (without pearlite) contributes to leveling its corrosion resistance to that of the API 5L X65 steel.

3. Impedance tests as a function of immersion time in sour medium pointed to a slight increase in corrosion resistance as the test proceeds, which was associated with the formation of a thick and non-adherent corrosion product layer (Fe and $\mathrm{S}$ ), which, nevertheless, offers a barrier against the diffusion of aggressive species.

4. API 5L X80 steel showed susceptibility to HIC, a fact not verified for API 5L X65 steel. The presence of Mn- and S-rich inclusions in the crack propagation pathway confirms that these microstructural features also play an important role in HIC failure in HSLA steels. According to the results of the present investigation this is the main reason why the API 5L X80 steel investigated in this study cannot be recommended for sour application.

\section{Acknowlodgements}

J.M. Quispe-Avilés and H. G. de Melo are thankful to CBMM for supporting this research through the project: "Pesquisa e Desenvolvimento de Aços ARBL".

\section{References}

1. Trench CJ, Kiefner JF; The U.S. Oil Pipeline Industry's Safety Performance. Oil Pipeline Characteristics and Risk Factors: Illustrations from the Decade of Construction. Washington: American Petroleum Institute; 2001: 54 p.

2. API - American Petroleum Institute. API 5L. Specification for Line Pipe. Washington: American Petroleum Institute; 2012. 12 p.

3. Koo JY, Luton MJ, Bangaru NV, Petkovic RA, Fairchild DP, Petersen $\mathrm{CW}$, et al. Metallurgical Design of Ultra High-strength Steels for Gas Pipelines. International Journal of Offshore and Polar Engineering. 2004;14(1):2-10.
4. Hashemi SH. Strength-hardness statistical correlation in API X65 steel. Materials Science and Engineering: A. 2011;528(3):16481655 .

5. Siciliano F, Stalheim DG, Gray MJ. Modern High Strength Steels for Oil and Gas Transmission Pipelines. In: Proceedings of the 2008 7th International Pipeline Conference; 2008 Sep 29 - Oct 3; Calgary, AB, Canada. p. 187-195.

6. Kawashima A, Hashimoto K, Shimodaira S. Hydrogen Electrode Reaction and Hydrogen Embrittlement of Mild Steel in Hydrogen Sulfide Solutions. Corrosion. 1976;32(8):321-331.

7. Gray JM, Siciliano F. High Strength Microalloyed Linepipe: Half a Century of Evolution. Houston: Microalloyed Steel Institute; 2009. p. 20-45.

8. Guo Y, Yang S, Shang C, Wang Y, He X. Influence of carbon contend and microstructure on corrosion behavior of low alloy steels in Cl- containing environment. Corrosion Science. 2009;51(2):242-251.

9. Haq AJ, Muzaka K, Dunne DP, Calka A, Pereloma EV. Effect of microstructure and composition on hydrogen permeation in X70 pipeline steels. International Journal of Hydrogen Energy. 2013;38(5):2544-2556.

10. Dong CF, Liu ZY, Li XG, Cheng YF. Effects of hydrogencharging on the susceptibility on X100 pipeline steel to hydrogen-induced cracking. International Journal of Hydrogen Energy. 2009;34(24):9879-9884

11. Barbosa GL, Cândido LC, Toffolo VR, Soares BLE. Microstructure and Mechanical Properties of Two Api Steels for Iron Ore Pipelines. Rede Temática em Engenharia de Materiais - REDEMAT Universidade Federal de Ouro Preto. 2014;17(1):114-120.

12. Fallahmohammadi E, Bolzoni F, Fumagalli G, Re G, Benassi G, Lazzari L. Hydrogen diffusion into three metallurgical microstructures of a C-Mn X65 and low alloy F22 sour service steel pipelines. International Journal of Hydrogen Energy. 2014;39(25):13300-13313.

13. Kim SJ, Kim KY. A Review of Corrosion and Hydrogen Diffusion Behaviors of High Strength Pipeline Steel in Sour Environment. Journal of Welding and Joining. 2014;32(5):13-20.

14. Mohtadi-Bonab MA, Eskandari M, Rahman KMM, Ouellet R, Szpunar JA. An extensive study of hydrogen-induced cracking susceptibility in an API X60 sour service pipeline steel. International Journal of Hydrogen Energy. 2016;41(7):41854197.

15. Prasad K, Dwivedi DK. Some investigations on microstructure and mechanical properties of submerged arc welded HSLA steel joints. The International Journal of Advanced Manufacturing Technology. 2008;36(5-6):475-483.

16. Qi YM, Luo HY, Zheng SQ, Chen CF, Wang DN. Effect of immersion time on the hydrogen content and tensile properties of A350LF2 steel exposed to hydrogen sulphide environments. Corrosion Science. 2013;69:164-174.

17. API - American Petroleum Institute. Specifications for Line Pipe ANSI/API 5L. Washington: American Petroleum Institute; 2007. $153 \mathrm{p}$. 
18. Qi YM, Luo HY, Zheng SQ, Chen CF, Lv ZG, Xiong MX. Comparision of tensile and impact behavior of carbon steel in H2S environments. Materials \& Design. 2014;58:234-241.

19. Davani RKZ, Miresmaelli R, Soltanmohammadi M. Effect of thermomechanical parameters on mechanical properties of base metal and heat affected zone of X65 pipeline steel weld in the presence of hydrogen. Materials Science and Engineering: $A$. 2018;718:135-146.

20. Zhao W, Yang M, Zhang T, Deng Q, Jiang W, Jiang W. Study on hydrogen enrichment in X80 steel spiral welded pipe. Corrosion Science. 2018;133:251-260.

21. Liu Q, Zhou Q, Venezuela J, Zhang M, Atrens A. The role of the microstructure on the influence of hydrogen on some advanced high-strength steels. Materials Science \& Engineering A. 2018;715:370-378.

22. ASTM International. ASTM E112-13 - Standard Test Methods for Determining Average Grain Size. West Conshohocken: ASTM International; 2013.

23. ASTM International. ASTM E45-13 - Standard Test Methods for Determining the Inclusion Content of Steel. West Conshohocken: ASTM International; 2013.

24. ASTM International. ASTM G106-89(2010) - Standard Practice for Verification of Algorithm and Equipment for Electrochemical Impedance Measurements. West Conshohocken: ASTM International; 2010.

25. NACE International. NACE Standard TM0284-2011-Evaluation of Pipeline and Pressure Vessel Steels for Resistance to HydrogenInduced Cracking. Houston: NACE International; 2011.

26. Stern M, Geary AL. Electrochemical Polarization I. A Theoretical Analysis of the Shape of Polarization Curves. Journal of the Electrochemical Society. 1957;104(1):56-63.

27. Arzola S, Mendoza-Florez J, Duran-Romero R, Genesca J. Electrochemical Behavior of API X70 steel in Hydrogen Sulfide-Containing Solutions. Corrosion. 2006;62(5):433-443.

28. Lucio-Garcia MA, Gonzalez-Rodriguez JG, Casales M, Martinez L, Chacon-Nava JG, Neri-Flores MA, et al. Effect of heat treatment on $\mathrm{H} 2 \mathrm{~S}$ corrosion of a micro-alloyed C-Mn steel. Corrosion Science. 2009;51(10):2380-2386.

29. Huang F, Li XG, Liu J, Qu YM, Ji J, Du CW. Hydrogen-induced cracking susceptibility and hydrogen trapping efficiency of different microstructure X80 pipeline steels. Journal of Materials Science. 2011;46(3):715-722.
30. Bolzon G, Boukharouba T, Gabetta G, Elboujdaini M, Mellas M, eds. Integrity of Pipelines Transporting Hydrocarbons - Corrosion Mechanisms Control and Management. Dordrecht: Springer Publishing, 2011.

31. Hladky K, Dawson JL. The measurement of corrosion using electrochemical 1f noise. Corrosion Science. 1982;22(3):231-237.

32. Jin TY, Cheng YF. In-situ characterization by localized electrochemical impedance spectroscopy of the electrochemical activity of microscopic inclusions in an X100 steel. Corrosion Science. 2011;53(2):850-853.

33. Huang H, Shaw WJD, Yen SK, Huang IB. Hydrogen Embrittlement Interactions in Cold-Worked Steel. Corrosion. 1995;51(1):30-36.

34. Hincapie-Ladino D, Falleiros NA. Trincamento induzido por hidrogênio em aços microligados. Tecnologia em Metalurgia, Materiais e Mineração. 2015;12(1):82-93.

35. Koh SU, Kim JS, Yang BY, Kim KY. Effect of Line Pipe Steel Microstructure on Susceptibility to Sulfide Stress Cracking. Corrosion. 2004;60(3):244-253.

36. Chen X, Li X, Du C, Liang P. Effects of solution environments on corrosion behaviors of X70 steels under simulated disbonded coating. Journal of Chinese Society for Corrosion and Protection. 2010;30(1):35-40

37. Wang H, Shaw WJD. Cold work effects on sulfide stress cracking of pipeline steel exposed to sour environments. Corrosion Science. 1993;34(1):61-68.

38. Zheng SQ, Qi YM, Chen CF, Li SY. Effect of hydrogen and inclusions on the tensile properties and fracture behaviour of A350LF2 steels after exposure to wet H2S environments. Corrosion Science. 2012; 60:59-68.

39. Sourmail T. A review of the effect of cold work on resistance to sulphide stress cracking. In: Proceedings of Corrosion 2007; 2007 Mar 11-15; Nashville, TN, USA. Paper 07104.

40. Arzola-Peralta S, Genescá Llongueras J, Palomar-Pardavé M, Romero-Romo M. Study of the electrochemical behaviour of a carbon steel electrode in sodium sulfate aqueous solutions using electrochemical impedance spectroscopy. Journal of Solid State Electrochemistry. 2003;7(5):283-288.

41. Zhang F, Pan J, Lin C. Localized corrosion behavior of reinforcement steel in simulated concrete pore solution. Corrosion Science. 2009;51(9):2130-2138.

42. Wang P, Lv Z, Zheng S, Qi Y, Wang J, Zheng Y. Tensile and impact properties of $\mathrm{X} 70$ pipeline steel exposed to wet $\mathrm{H} 2 \mathrm{~S}$ environments. International Journal of Hydrogen Energy. 2015:40(1):11514-11521. 